\title{
Indonesian Travelling Women with Cultural Studies Perspective
}

\author{
Sri Hartiningsih \\ University of Muhammadiyah Malang \\ Malangharti2001@yahoo.com
}

\begin{abstract}
Travelling occurs as one could not deny interacting with the other. Human interaction may see, hear, touch, smell, taste and interact with the real thing. Therefore, travelling makes great hunger to see the other in person as at heart of tourism is person to person relationship. Dealing with travelling, Malang travelling women are dug out. In specific, it tends to discover the motif, type and cultural barrier of Malang travelling women going abroad. The subject of this research is Malang travelling women. The consideration is Malang is well known as educational city that makes especially women developing their potentiality. Another reason is its condition provides women to have chance to travel abroad. To select the data, it is needed purposive sampling as found nine informants using interview. The finding shows that the motives of Malang travelling woman abroad are short course, social mission, exhibition, pleasure, cooperation, seminar and comparison study. The type of travelling of Malang travelling women is all Malang travelling women are adventurer, exploiting and alternative tourist. All Malang travelling women do not encounter cultural barrier in their travelling abroad as improving knowledge of other countries through cinema and television.
\end{abstract}

Keywords: traveling women, motif, cultural barrier

\section{INTRODUCTION}

Travelling is a part of tourism. It is "organized journey out and home again during several or many places visited [1]. It means that the tourist does not stay permanent and he or she is going back to her or his previous place and tourism is "a part of leisure time activity distinct from work and home that enable individuals to spend a period of time in a new place or places" [2]. In detail, it is "the temporary short-term movement of people to destination outside the place where they normally live and work, and activities during their stay at these destinations: it includes movement for all purposes, as well as day visits and excursions [3] and tourism as social interaction [4]. In practice, commonly tourism as the activities of persons travelling to and staying in place outside their usual environment for not more than one consecutive year for leisure, business, and other purposes [5]. This implies that the tourist intends to get pleasure and find out something different.
Tourism is industry that gives less effect towards environment if it is compared with the other big industry as mining, manufacture, textile, automotive and pharmacy so it is well known as industry without smoke stack. The service activity that emphasizes on this aspect of service and hospitality is closed relationship with the aesthetic of nature and the attractive of culture. Therefore, developing tourism is not only chosen by Indonesia especially Bali but almost all nations in the world make tourism as pledge development. Nowadays tourism has become global industry that provides $10.6 \%$ world work force [6] and tourism has a profound important in the contemporary world as before the rise in the price of oil in the early 1970s, tourism was the largest item in the world trade [7]. Besides, Indonesia is recorded by WTO as one rapid tourism development in Asian region.

To get that opportunity, Indonesia government gives priority towards tourism. It can be proved that there is a ministry that manages tourism department. It is done to introduce Indonesia culture and the beautiful panorama towards domestic society and especially international, also the most important thing is increasing foreign exchange for the country. This means the more developed tourism, the more might give prosperity for Indonesia. Those are the reason why government continues developing tourism by expanding industry tourism, increasing the total number of domestic tourist as well as abroad, travel also accommodation. It also improves tourism facility. All are done to make the tourist prolong to stay in Indonesia [8].

Related to tourism, travelling is certainly the way to see something new [9], broadens the mind [10] although there are media such as television, mobile phone as well as internet [11].

Travelling that motives for travelling in industrial societies has undergone a huge transformation and that modern travel may also be rightly considered in a positive sense as one of the great social achievement of over time [11]. Furthermore, in the sort of world we inhabit today, interactions with other cultures are something that cannot be avoided since the technological advances in communication, transportation and business have broken down the national barriers [12].

Those mean that travelling makes one know the others as a proverb in Indonesia says "tidak kenal maka tidak sayang" and interact directly that makes living in harmony with society in local, national as well as international that needs concept of "the otherness" which 
appreciates differences and is celebrated by post-modern [13]. The difference is not bad. It means man should not be expected to do the same thing as we do and should not be judged not perfect or bad [14] (Fay, 1998:92) except appreciating the difference and not forcing the others. Here is the beautiful of pluralism [15] (Astawa, 2005:56) as if everybody has own sensitive and awareness towards the difference, one is not going to find out the difference but how to look for the similarity from that difference to make strength and opportunity that can be developed to get the better life of being nation, state and society. The main principle is appreciating the difference and not forcing someone else to do the same thing.

Pluralism means plural, some and many cases. So something is called plural consists of some cases, some kinds, some points of view and backgrounds [16]. Related to "guest-host relationship of tourism, it is often the women of the host environment who draw the attention of the researcher [17]. That is why tourist women are going to dig out in this research.

Based on the background of the research, the problems are: What are motives of travelling women? What type of travelling are travelling women?, and What cultural barriers do travelling women encounter?

\section{METHOD}

The research design used in this research is descriptive study. It means that this research describes travelling women especially deals with motive, type of travelling as well cultural barrier faced.

The subject of this research is Malang travelling women. Malang is taken by consideration that Malang is well-known as an educational city as it is proved there are state universities as Brawijaya, Malang, Islamic state university, State University of Malang, and Malang state Polytechnic as well as private universities such as Muhammadiyah University of Malang, UNISMA, ITN, UNMER, Widyagama, Malang Kuceswara and the others. This makes especially women develop their potentiality. Another reason is its condition provides women to have chance to travel abroad.

To select the data, it is needed purposive sampling. It is found nine informants. The instrument used to get data is unstructured interview to make natural condition by giving guided interview. The result of interview then is tabulated and interpreted based on the problems have been stated.

\section{RESULT}

This part describes the research problem stated. They are the motif, type and cultural barrier occur in Malang travelling women.

\section{Travelling Motif}

All Malang travelling women travelling abroad are statues and prestige motivator. They are in the form of joining short course, seminar, comparison study, and accompanying Kangmas and Mbakayu Malang to have exhibition, pleasure, cooperation although the time and the country are different. Relating to motif of travelling, whatever motif of travelling of Malang travelling women, all of them want to get pleasure in their travelling abroad.

Dealing with Maslow's need hierarchy, it can be said that all Malang traveling women do not belong to the lowest level of need, physiological need such as food, water and shelter. That is why they are able to travel abroad as they do not have problem for alive as all the women come to the fourth level of need. The statues and prestige motivator belongs to esteem need that is in the fourth level, includes both self-esteem (self-respect) and public esteem. People want a high self-image as well as the respect and admiration of others. These needs take two different forms. First, they have a need for competency, confidence, and independence. They also want the prestige, statues, recognition, and appreciation that others bestow on us. Satisfying the esteem needs produces feeling self-worth; not satisfying them produces feelings of inability and inadequacy. It does not always mean the lower hierarchy needs have been achieved as most of them get fund or being sponsored to go abroad, except one woman saving the money for joining seminar. In fact statues and prestige they have got after making traveling abroad as they have experience, brand image of abroad as Indonesian believes that abroad is guarantee of excellence of everything.

\section{Type of Travelling}

Relating towards Burn and Holden's types of travelling, all Malang travelling women are adventurer as the characteristics of adventurer tourist are ones is motivated to seek new experience, value diversity, seeking new activity, culture and people. Beside adventurer tourist, Malang travelling women ars considered exploiting ones as use the others for the sake of herself as they use the fund they have got as maximal as they can as they have short course, exhibition, cooperation as well as comparison study but they try to see the tourism objects provided by its country based on their interest and background. They are also called the alternative tourist is they come to certain place for the sake of joining seminar, course or exhibition but they are also curious to know other people and their culture.

\section{Cultural Barrier}

Based on the interview, all Malang travelling women do not encounter cultural barrier in their travelling abroad. It is surprising that different ethnic especially nation commonly creates conflict if they meet especially in interaction.

Different in type, motif and behaviour pattern could create conflict as different thing such as religion and nation that interact may possible create conflict [16]. In specific, different type, motif and behaviour pattern could create conflict but not all conflicts are negative if it is considered as natural, moreover different is not always bad and one could not force the other to do the same 
thing like her or him. Further, one will consider the difference as funny as one of Indonesian travelling woman, went to New Zealand. After having seminar she went home. She took a rest by sitting in halt bus as commonly happened in Indonesia. How surprise she was when the driver of bus told her that sitting at halt bus means directly got on the bus. The conflict did not occur as the driver knew she was a foreigner in that place and for her it is funny thing as she did not know it. It is also supported by interview with travelling women that type, motif and behaviour are not cultural behaviour anymore as the difference is appreciated whereas before it only frightened. It occurs as improving knowledge of other countries through cinema and television [10]. This is called multiculturalism

Related to barrier, travelling barriers are divided into six categories. They are cost, lack of time, health limitation, family stage, lack of interest, and fear and safety [18].

Dealing with barrier in travelling nowadays the most barrier is fear and safety. Fear and safety is related to politic of destination country as separatism in that place, natural disaster as flooding, earthquake or flue epidemic, and warning from their country to certain countries. The safety is the priority of every traveller to choose the destination country. The cost of travelling is not quite barrier as the travellers now having good income or they can save the money for travelling. In addition, the accommodation and transportation are able to fulfil as the development of vehicle technology so that the transportation is cheaper than previous years. Limited time is able to manage as now the labour rule to give the holiday for the employees in one week or in one year so everyone can manage it. Currently, certain institutions or manufactories give bonus for travelling in certain occasions such as at the end of year, Moslem's big celebration, Idhul Fitri, Christmas time, Galungan for Hindu, Waisak for Budha. As the growth of income is much better so the health is getting better and some of travellers make travelling for the sake of their health as certain country makes the traveller recovery. Family stage is not barrier anymore as the activities suit with their age and there is a guide or baby sitter to help them.

\section{CONCLUSION}

Based on the finding above, it can be concluded that the motives of Malang travelling women going abroad are short course, social mission, exhibition, pleasure, cooperation, seminar and comparison study.

The type of travelling of Malang travelling women is all Malang travelling women are adventurer as motivated to seek new experience, value diversity, seeking new activity, culture and people. Beside adventurer tourist, Malang travelling women is considered exploiting ones as use the others for the sake of herself as they use the fund they have got as maximal as they can as they have short course, exhibition, cooperation as well as comparison study but they try to see the tourism objects provided by its country based on their interest and background. They are also called the alternative tourist as they are not only coming to certain places for joining seminar, course or exhibition but also for their curiosity to know other people and their culture.

All Malang travelling women do not encounter cultural barrier in their travelling abroad. It is surprising that different ethnic especially different nation commonly creates conflict if they meet, in fact it does not. It occurs as people have more and understanding of other countries through cinema and television.

Based on this research, some things are not revealed yet. Therefore, some suggestions are presented to observer of cultural and social, related to travelling, and government as decision maker as follows:

1. Knowing foreign culture could be done by reading literature for those who do not have enough money and time to go abroad.

2. Before travelling, it is suggested learn the culture of the country which is going to visit in order to avoid cultural barriers.

3. Cross culture understanding is really necessary given to the doers' tourism but also to all institutions in order to reduce misunderstanding and appreciate the other.

\section{REFERENCES}

[1] Hornby, AS. Oxford Advanced Learner's Dictionary of Current English. England: Oxford University Press, 1983.

[2] Byrne Swain, Margaret. Annal of Tourism Research:Gender in Tourism.USA: Pergamon, 1995

[3] Richards, G. Cultural Tourism in Europe: The Social Context of Cultural Tourism. London: CAB International, 1997.

[4] Swain, Margaret. Annals of Tourism Research: Gender in Tourism. USA: Pergamon, 1995.

[5] Gee, Chuck Y. International Tourism: A Global Perspective. Spain: World Tourism Organization, 1999.

[6] Asrama, B. Merekam Pariwisata Bali dalam 35 tahun, Narasi Mencemaskan bagi Sustainable Tourism Makalah seminar dan Lokakarya Nasional Bali Tourism Sustainable development and Law Inforcement, Inna Grand Bali beach Sanur 25 Februari 2006.

[7] Crick, Malcolm. The Sociology of Tourism: Representations of International Tourism in Social Sciences; Sun, Sex, Sights, Savings, and Servility. London: Routledge, 2002.

[8] Hartiningsih, Sri. Hotel Vacancy in Malang for English Language Graduates. Malang: UMM, 2004.

[9] Verne, Jules. Round the World in Eighty Days. Jakarta: P.T Gramedia Pustaka Utama, 2003.

[10] Burn, Peter M. \& Andrew Holden. Tourism: a new perspective. UK: Prentice Hall, 1995.

[11] Nuryanti, Windu. Tourism and Culture: Global Civilization in Change. Yogyakarta: Gadjah Mada University Press, 1996. 
[12] Winardi, Andreas. Representation of Cultural Values in Language and Literature: The Utilization of Literature to Develop The Understanding of Other Culture. Semarang: Soegijapranata Catholic University, 2005.

[13] Piliang, Yasraf A. Antara Homogenitas dan heterogenitas: Estetika dalam Cultural Studies. Makalah Guest lecture di Pasca Sarjana, Kajian Budaya, Universitas Udayana, 2006.

[14] Fay, Brian. Filsafat Ilmu Sosial Kontemporer. Yogyakarta: Penerbit Jendela, 1998
[15] Astawa, I Nengah Dasi. Sisi SWOT Multikulturalisme Indonesia. Jurnal Kajian Budaya Universitas Udayana, 2005.

[16] Tanuwibowo, Budi S. et.al. Pluralisme, Konflik Dan Perdamaian. Yogyakarta: Pustaka Pelajar, 2002.

117] Butler, Kathleen L. Annals of Tourism Research: Independence for Western Women Through Tourism. USA: Pergamon, 1995.

[18] McIntosh, Robert W. and Goelner, Charles W. Tourism: Principles, Practices, Philosophies. USA: John Willey \& Sons Inc, 1990. 